\title{
Evaluating the success of international sanctions: a new research agenda
}

\section{La evaluación del éxito de las sanciones internacionales: una nueva agenda investigadora}

\section{Lee Jones}

Reader in International Politics, Queen Mary University of London, UK. I.c.jones@qmul.ac.uk. ORCID: https://orcid.org/0000-0003-1290-5141

\section{Clara Portela}

Faculty member in Political Science, University of Valencia, Spain. clara.portela@uv.es. ORCID: https://orcid.org/0000-0001-9289-3245

How to cite this article: Jones, Lee and Portela, Clara. "Evaluating the success of international sanctions: a new research agenda". Revista CIDOB d'Afers Internacionals, issue 125 (September 2020), pp. 39-60. DOI: doi.org/10.24241/rcai.2020.125.2.39/en

\begin{abstract}
Sanctions scholarship generally considers sanctions to be "successful" when targets comply with sender' demands. This form of evaluation is inadequate. Firstly, without a robust methodology it is hard to determine whether sanctions produce compliance. Secondly, sanctions tend to pursue goals beyond those announced, which may relate to the target, the sender itself or the international system. An evaluation of the effectiveness of sanctions must identify all these goals, recognise their interrelations and measure their success with the help of interpretative methods.
\end{abstract}

Key words: international sanctions, methodology, evaluation, compliance, efficacy
Resumen: La investigación sobre sanciones internacionales considera mayoritariamente que estas alcanzan el "éxito» cuando los destinatarios cumplen con las exigencias del emisor. Sin embargo, esta forma de evaluar es inadecuada porque: en primer lugar, no se ha desarrollado aun una metodología sólida que permita determinar si las sanciones generan cumplimiento; $y$, en segundo lugar, las sanciones persiguen metas que pueden diferir de las declaradas, e ir dirigidas a los destinatarios, al propio emisor o al sistema internacional. La evaluación debe identificar las diferentes metas, reconocer sus interrelaciones y medir su éxito con métodos interpretativos.

Palabras clave: sanciones internacionales, metodología, evaluación, cumplimiento, eficacia

The authors thank two anonymous reviewers, as well as Dr Andrea Charron, for comments on an earlier version of this article. Research for this article was funded by ESRC grant (RES-06 1-25-0500) for the project 'How Do Economic Sanctions (Not) Work?'. This article is also linked to the project "Public Security, Private Security and Fundamental Rights" (RTI2018-098405-B-100) from the Spanish Ministry of Science, Innovation and Universities. 
Research on international economic sanctions has focused heavily on the question of whether they are successful in delivering the goals sought by their "senders", i.e. the countries that imposed them. Assessments have evolved over time, from widespread pessimism in the 1970 s, to a new optimism from the mid-1980s to the late 1990s, followed by a period of more critical reflection, during which more diverse research questions emerged. The central debate over whether sanctions "work" exhibited a curiously backwards development. It began from the premise that the purpose of sanctions is to compel target states to concede to senders' stated demands, and assumed that measuring whether this occurs is relatively unproblematic. The key methodological question - how can we tell whether sanctions work? - was not debated until the late 1990s, when the battle lines for and against the efficacy of sanctions were already entrenched. The more fundamental definitional question - what are the purposes of sanctions? - has hardly been considered. Most scholars still assume that sanctions are merely about the sender trying to compel compliance from a target. This ignores research insights available for over four decades that sanctions are actually used to pursue diverse objectives, including goals related to domestic politics and the international system, not just target states (Barber, 1979; Lindsay, 1986; Hoffmann, 1967). Consequently, much of the research on whether sanctions work is fundamentally flawed, since it does not specify adequately what sanctions are meant to accomplish, nor how we can assess whether they succeed in meeting these objectives.

The first section of this article critiques the mainstream sanctions literature and urges a return to the earlier, classical work on sanctions that emphasised the myriad purposes they serve. It also corrects some of the shortcomings of some of this early scholarship - particularly its unjustified assumption that target-related goals are "primary" for senders. The article's second section articulates three clusters of goals related to the target, the sender, and the international system. We also underscore the importance of recognising the inter-related nature of these three clusters. However, we also argue that there is a risk that the definition of "success" is widened merely to salvage sanctions from criticism that they are ineffective. To avoid this, we should reflect critically (and normatively) upon the relative importance of different clusters of goals. 


\section{The atypical evolution of sanctions evaluation scholarship}

The evolution of sanctions evaluation scholarship can be sketched in three main phases. In the first phase, analyses were largely qualitative, case studybased and overwhelmingly negative. Sanctions research began with Galtung's (1967) examination of the effects of the United Nations embargo on Rhodesia. His seminal analysis concluded that the embargo had not weakened the Rhodesian regime but had instead strengthened its grip on power. This negative judgement, echoed by other scholars, produced a consensus that sanctions were invariably ineffectual in compelling targets to change their policies (Doxey, 1980; Wallensteen, 1968). This was ascribed to their inherently flawed logic, described by Galtung as the "naïve theory of sanctions". According to this theory, sanctions are expected to generate sufficient economic deprivation to galvanise the population against the leader, thereby compelling them to concede to the demands of the sender. Galtung's findings refuted such expectations: the economy adapts to new circumstances, individuals adjust to hardship or even exploit sanctions-busting opportunities, and rulers can instrumentalise deprivation to rally the nation "around the flag". Given their belief that sanctions were ineffectual, scholars expended little further intellectual effort in considering how, or whether, their effects could be measured.

A second, more optimistic phase began with the publication of Hufbauer, Schott and Elliott's (1985) large-N study, Economic Sanctions Reconsidered (aka 'HSE'). Breaking with established wisdom, it claimed that 34 per cent of twentieth-century sanctions regimes had been successful, inaugurating a more optimistic period, where scholars actively advocated the use of sanctions (Baldwin, 1985; Elliott and Uimonen, 1993; Cortright and Lopez, 2000). Some contested HSE's validity by proposing more sophisticated models, or questioning the coding of their data, insisting that sanctions still did not work (Tsebelis, 1990; Pape 1997). Nevertheless, HSE proved enormously influential, becoming the standard dataset for future research (Brzoska, 2013), not least because it long constituted the only extant database.

The third phase of research consisted of two main strands. The first comprised a relatively short-lived debate around HSE, which - at long last - began asking the question of how to judge the success of sanctions (Pape, 1997 and 1998; Elliott, 1998; Baldwin and Pape, 1998; Drury, 1998). Pape's (1997 and 1998) particularly biting critique of HSE argued that they had simply mischaracterised many cases as successes: targets' concessions were either wrongly 
classified, or generated by factors other than sanctions. However, as discussed below, this crucial methodological challenge was largely ignored. A second strand of research instead saw the subfield, having essentially accepted HSE's revisionist claim that sanctions could sometimes work, reorient around the question of when they worked, sparking extensive investigation of features of the sanctions regime or the target (Kirshner, 1997; Drezner, 1999; Blanchard and Ripsman, 1999; Rowe, 2001; Brooks, 2002; Lektzian and Souva, 2007; Escribà-Folch, 2012). This occurred alongside a sharp increase in sanctions activity by non-US senders, primarily the United Nations, after the Cold War (Borzyskowski and Portela, 2018), which considerably enlarged the empirical basis for such studies. However, this scholarship continued to assume that compelling compliance from the target was the hallmark of success, and ne-

Sanctions research evolved in 'reverse' order: A logical sequence would have involved establishing how to determine the goals of sanctions before discussing how to assess their outcomes.

glected the methodological question of how success could be determined.

Sanctions research has therefore evolved in a counterintuitive fashion. Arguments about the success rate of sanctions (first and second phase) preceded any discussion of how (or even whether) their efficacy can actually be evaluated (third phase). Furthermore, both the success rate and the methodology were debated before anyone questioned whether sanctions were actually meant to achieve their stated objectives (Chesterman and Pouligny, 2003). Thus, sanctions research evolved in 'reverse' order: A logical sequence would have involved establishing how to determine the goals of sanctions before discussing how to assess their outcomes (Portela, 2010). This is largely because the sanctions subfield has evolved in close connection to policy debates, which are typically polarised between advocates and detractors of sanctions as policy tools. Only belatedly have sanctions scholars conceded that measuring success on the basis of whether they "appeared to contribute to the achievement of stated policy goals" (Elliott, 1995: 52) may be unsatisfactory in light of the multiple goals they serve.

\section{Identifying multiple goals}

The subfield's inverted development is ironic given that some of the earliest work on sanctions was directly concerned with elucidating the multiple goals that sanctions served and the associated difficulty of evaluating their "success". This early research emphasised that sanctions fulfil several functions 
and that the accomplishment of senders' stated goals vis-à-vis target is only one of them.

That senders impose sanctions to pursue multiple goals beyond their publicly stated ones was recognised early on. Galtung (1967: 409) posited that alongside narrow, target-related goals, sanctions aimed "to punish the receivers by depriving them of some value and/or to make the receivers comply with certain norms". Galtung therefore measured success in terms of punishment (the degree of economic deprivation inflicted) as well as compliance with senders' political demands. Barber (1979) went further, distinguishing between primary, secondary and tertiary objectives, which related to different audiences. Primary objectives are concerned with the actions and behaviour of the target: sanctions seek to induce compliance with senders' declared policy objectives. Secondary objectives relate to domestic audiences: sanctions are applied "to demonstrate the effectiveness of the imposing government... [to show] a willingness and capacity to act" or "to anticipate or deflect [domestic] criticism" (ibid.: 380). Tertiary objectives relate to wider international audiences and concerns, such as a desire to maintain a "pattern of behaviour in international affairs", or "support for a particular international structure, such as the League of Nations" (Barber, 1979: 382; also Hoffmann, 1967). Further goals, such as "subversion" and "deterrence" (Lindsay, 1986; Miller, 2014) were later added to Barber's three-fold distinction.

While Barber (1979: 381) did not elaborate on how these goals related to one another, he argued that the fulfilment of his "secondary" or "tertiary" goals did not depend on the achievement of his "primary" goals. This implies that sanctions' efficacy cannot simply be determined by the degree of compliance from targets. Yet this is precisely the approach taken by all subsequent mainstream sanctions research. Without engaging with this early work, scholars have generally focused exclusively on "primary" goals, i.e., the extent to which the target is forced to comply with the senders' publicly-stated goals. Yet if senders often intend sanctions to serve multiple goals, this narrow focus does not measure whether the instruments are successful in the eyes of the policymakers who impose them. Furthermore, the importance allocated by senders to the different objectives might vary over time (Barber, 1979), and compliance might not be the most important goal; indeed, it may not even feature among the objectives (Lindsay, 1986). As two UN officials rightly complain, "Most studies on the efficacy of sanctions ignore the fact that they may do more than simply seek to coerce states to change their behaviour. In fact, the variety of goals, other than coercion, that the Security Council may pursue by imposing sanctions is considerable... Reviews of the utility of 
sanctions occasionally note these additional roles that sanctions may play, but almost never examine them in any detail" (Mack and Kahn, 2000: 285-286).

While scholars occasionally gesture towards the multiplicity of goals, they largely constrain themselves to measuring compliance on the grounds that it is too difficult to assess efficacy in relation to other goals. Early scholarship offered initial methodological guidance on assessing multiple goals. Barber (1979) argued that because some functions of sanctions could be fulfilled virtually automatically, their success could be assessed straightforwardly. The "secondary" and "tertiary" goals of enhancing a government's domestic popularity, upholding international norms and demonstrating resolve to allies, for example, may be automatically fulfilled upon the announcement of the measures (Doxey, 2000: 214) and thus be considered "successful" as soon as they are imposed (Elliott, 2010: 88). However, for various other "secondary" and "tertiary" goals, Barber believed it impossible to assess efficacy, a view shared by others (Elliott, 2010: 88). While accepting that it is methodologically challenging, Lindsay (1986) attempted to evaluate the effectiveness of all of the five goals he identifies, such as the increase in popularity of certain US presidential candidates in the aftermath of the imposition of sanctions. Yet with the prevalence of the quantitative approach to sanctions research (Peksen, 2019), the potential value of these finelygrained, qualitative judgements remains underdeveloped.

Recent scholarship has slightly expanded the focus beyond compliance by considering two additional functions: constraining the target, and signalling (Biersteker et al., 2016; Elliott, 2010; Giumelli, 2016; Jones, 2018). According to this approach, "operational objectives fall into three broad and overlapping categories - to signal disapproval, to deny or contain, or to coerce" (Elliott, 2010: 87). This is positive insofar as scholars are beginning to accept that goals exist beyond eliciting targets' compliance and that their attainment should be assessed. Nonetheless, this scholarship remains limited by its continued focus on the sender-target relationship, without exhausting the full range of senders' objectives. Arguably, the goal of "signalling" is accomplished automatically: every time a sanction is imposed, it sends a signal. Rather than marking a fundamental rethink of evaluation methodology, this approach seems rather to rescue sanctions from criticism by demonstrating their effectiveness beyond their coercive capacity. Thus, unsurprisingly, an analysis of UN targeted sanctions found higher success rates for the goals of constraining and signalling than for coercion (Biersteker et al., 2016). Despite its innovative character, this evaluative framework remains locked into a partisan position the subfield's original debate: do sanctions work? 


\section{Assessing "success"}

The dominant, narrow focus on compliance might seem to imply that a meaningful method for measuring success against these goals has been established; but nothing is further from the truth. The debate between Elliott and Pape (Pape, 1997 and 1998; Elliott, 1998) and later between Pape and Baldwin (Baldwin and Pape, 1998) was precisely about methodological disagreements over the measurement of success of sanctions. While the methodological misgivings expressed by researchers about HSE's methodology are manifold (Pape, 1997; Drury, 1998), the key issue in the Elliott-Pape exchange was how to prove that sanctions caused compliance. This question was never resolved. Establishing causality remains the core problem of research on sanctions efficacy: it is extremely difficult if not impossible - to demonstrate conclusively that sanctions, and not some other cause, produced the target's decision to comply. This is particularly challenging because sanctions are often part of a broader strategy involving the concurrent deployment of other

Galtung's "naive theory" (1967) - whereby economic deprivation caused by sanctions generates discontent and unrest, creating a "societal transmission belt" that pressures ruling elites to conform to the sender's demands - is no longer regarded as the only way in which sanctions can induce compliance. policy instruments.

Suggestions for a more rigorous methodology did emerge from this debate. Pape (1998: 98) suggested that sanctions should be credited with success if they met three criteria: (a) the target state concedes to a significant part of the coercer's demands; (b) economic sanctions are threatened or applied before the target changes its behaviour; and (c) no more-credible explanation exists for the target's change of behaviour. This third point is further specified by the timing of concessions in relation to specific military threats or economic sanctions, and the statements by the target state's decision makers. Yet, despite their apparent stringency, Pape's criteria are still problematic. Statements by parties to the dispute are not reliable sources, as both sides have incentives to misrepresent the motivations behind any concessions. Because sanctions often co-exist with other external instruments, and also because domestic forces which influence target governments independently, the claim that sanctions do contribute to compliance in one way or another is difficult to either falsify or validate. Arguably, this is may be the reason why sanctions scholars largely ignored Pape's challenge. 
A large part of the reason why it is so difficult to establish a conclusive causal link between sanctions and compliance is that the mechanisms through which sanctions are meant to work have scarcely been studied. The subfield's many case studies suggest that sanctions can accomplish or contribute to their target-related aims in a variety of different ways. Galtung (1967) delineated the "naive theory" of sanctions, whereby economic deprivation caused by sanctions generates discontent and unrest, creating a "societal transmission belt" that pressures ruling elites to conform to the sender's demands. This causal pathway - which, although quickly discredited, nevertheless underpinned HSE's methodology - is no longer regarded as the only way in which sanctions can induce compliance. As Baldwin observes, "there are many causal logics that could be used to construct a variety of theories of economic sanctions" (Baldwin and Pape, 1998: 193). However, only a handful of studies have begun to identify a few of these. In South Africa, Crawford and Klotz (1999) suggested that sanctions worked through diverse mechanisms, including "resource denial", "normative communication" and "political fracture", thereby "creating the conditions" that facilitated the end of apartheid (ibid.). Financial sanctions "sharpened divisions between the while oligarchy", and thus "contributed significantly to the economic and political climate which fostered" reforms (quoted in Kirshner, 2002: 177). These "indirect" modes of operation complicate the tasks of establishing or falsifying the causal link between sanctions and any given political outcome. What is needed - at least for target-related goals is a theory of domestic political change and how sanctions connect to this (e.g. Jones, 2015).

\section{Wrong debate?}

The flawed evolution of sanctions scholarship stems from scholars' desire to provide guidance to the policy community. Firstly, when investigating sanctions efficacy, scholars formulated the research question that (they felt) policymakers were interested in, namely, whether sanctions work. This implied divorcing analysis from normative evaluation: Baldwin (2000: 81) argued scholars should "separate the question of whether sanctions work from that of whether they should be used". However, as Kirshner (2002: 168) notes, scholars have consistently prioritised the first question while disregarding the second. The evaluation of the multiple functions of sanctions, with its potentially fruitful consequences for both questions, has only been timidly explored. 
Secondly, framing evaluation in these terms had major implications for research design, not least for the definition of the standard of success and its measurement. As Kirshner (2002: 168) observes, "the audience is policymakers, and the purpose is to guide policy - bottom line, practical stuff". The conflation between the research interests of scholars and the interests of policymakers is illustrated by Pape's statement that "the central policy purpose of economic sanctions (...) is behaviour modification. If the target state concedes to the coercer's demands, policymakers will normally consider that a success" (Baldwin and Pape, 1998: 197). Pape equates what policymakers want to know and what scholars should investigate, rejecting the suggestion "that most policymakers would feel well served by analyses that abandon this standard" (ibid.: 198). Not only does this wrongly imply that scholars should only do what

The flawed evolution of sanctions scholarship stems from scholars' desire to provide guidance to the policymakers, prioritising sanctions' efficacy while disregarding the issue of sanctions' objectives.

policymakers find useful, it is contradicted by the UN officials' complaint about sanctions scholarship cited above.

\section{Re-thinking sanctions goals beyond the convention}

Having identified some important shortcomings in the framing of efficacy scholarship, what could a "corrective" research agenda look like? This section reappraises the multiple goals implicit in sanctions regimes, and their interconnections, and proposes a fresh approach to evaluate success. Our starting point is that attempts to measure success by focusing on compliance alone cannot suffice, yet the other goals being pursued are rarely directly observable by scholars. Therefore, specifying the goals of any sanctions regime and assessing how far they are achieved can only ever be an interpretive act - in contrast to the positivist approach favoured in extant scholarship. As Doxey (2000: 214) notes, "governments do not always articulate publicly the full range of their motives and objectives in imposing sanctions. Typically, they stress the unacceptable nature of the target's behaviour and their own dedication to international community values, but these claims do not give a wholly accurate reflection of their policy thinking". 
Their "motives and objectives" must therefore be interpreted by scholars. While this may discomfort positivists, there is no other way to specify goals beyond target-related compliance. Moreover, focusing exclusively on directly observable, "publicly-stated demands" is "to load the dice in favour of failure" (Baldwin, 1985: 132). Paradoxically, it generates a distorted understanding of sanctions and poor policy prescriptions, despite mainstream scholars' concern to provide the opposite. Perhaps more importantly, an interpretive and critical approach is required to avoid credulous acceptance, at face value, of policymakers' justifications. We therefore elaborate a framework for interpreting and categorising the goals of sanctions and assessing their fulfilment. These goals are described as target-related, sender-related and system-related, rather than as Barber's (1979) "primary", "secondary" and "tertiary" categories, which unjustifiably hierarchises sender motives. As Doxey (2000: 211) rightly observes, "a fixed ranking of goals suggests a hierarchy not always borne out in practice".

\section{Target-related goals}

Although target-related goals are often assumed to be unproblematically specified, this is rarely the case. Certainly, senders' target-related goals may reflect the publicly-stated aims that are the focus of most sanctions scholarship. Typically, scholars identify the public terms of the sender-target dispute, then observe whether the target modifies its behaviour in response to sanctions: "compliance ultimately determines effectiveness". (Cortright and Lopez, 2000: 209). Target-related goals may include regime change, weakening of military potential, disrupting military operations (Hufbauer et al., 1985), blocking the acquisition of sensitive or strategic assets (Baldwin, 1985; Shambaugh, 1999), or effecting specific policy changes on anything from non-proliferation to human rights (Fayazmanesh, 2003; Gordon, 2010).

However, senders' target-related goals frequently diverge from those they state publicly. In some cases, they actually seek more ambitious objectives. Illustratively, the UN Security Council ostensibly imposed sanctions on Iraq in 1990 to compel it to withdraw from Kuwait, and subsequently to destroy its weapons of mass destruction. Yet the UK and the US also announced that they would veto any resolution designed to weaken sanctions against Iraq as long as Saddam Hussein remained in power (Chesterman and Pouligny, 2003: 508509). Thus, although the sanctions regime's formal goal was Iraq's disarmament, the end actually being sought by London and Washington was regime change (Gordon, 2010). In other cases, senders' true goals are more modest 
than those publicly-announced. They may formally demand regime change, but may in truth be seeking only to impose sufficient costs to elicit negotiations and some concessions (Cortright and Lopez, 2000). Although the Bush administration allegedly sought regime change in Myanmar, the US Burma Freedom and Democracy Act of 2003 listed several less-ambitious goals, including "to sanction the ruling Burmese military junta, to strengthen Myanmar's democratic forces, and recognise the National League for Democracy as the legitimate representative of the Myanmar people" (US Government, 2003). Here, sanctions were used to manipulate the balance of power between domestic political forces in favour of the opposition. Consequently, their success would not be accurately measured solely by whether regime change occurs, but also by how far they bolster some groups' power and legitimacy, while weakening others'.

Given that target-related goals Senders' target-related goals frequently are more complex than is common- diverge from those they state publicly. In ly admitted, assessing the degree to some cases, they actually seek more amwhich they are achieved requires an bitious objectives. interpretive methodology. Even to

define target-related goals is not straightforward but requires interpretation in the light of contradictory statements and other evidence besides senders' formally-stated aims. Moreover, given the variety of forces influencing the leadership of any target state, a behaviouralist cause-effect approach that seeks to correlate concessions to the imposition of sanctions will struggle to prove that sanctions produced those concessions. A more persuasive account would instead trace the impact of sanctions through a domestic theory of change, showing how they filter through domestic political struggles into particular outcomes (Kirshner, 1997; Crawford and Klotz, 1999; Blanchard and Ripsman, 2008; Jones, 2015). This will involve disaggregating the state and using insights from political sociology, comparative politics and political economy. These methods do not immediately lend themselves to large-N, quantitative studies but are clearly necessary to acquire the basic knowledge of sanctions episodes on which such studies ought to be based.

\section{Sender-related goals}

One of the by-products of the current emphasis on compliance - which has generated a consensus, even among optimists, that sanctions generally fail about two-thirds of the time - is scholarly puzzlement about why sanctions 
are still used despite this lacklustre record. Baldwin (1985) rightly insists that sanctions are used because the alternatives, like doing nothing or waging war, are either less effective or too costly. However, another reason is that they can fulfil senders' domestic objectives.

Several scholars suggest that sanctions are intended to serve domestic purposes (Drury, 2001). Some argue that the severity of sanctions regimes depends on the interplay of domestic interests in the sender state(s) (Kaempfner and Lowenberg, 1992; Letzkian and Souva, 2007). Sanctions detractors often allege that these measures are only used for appeasing domestic constituencies hostile to the target (Haas, 1997; Preeg, 1999; Thinan Myo Nyun, 2008). Ample evidence suggests that sanctions regimes are imposed in response to campaigning by powerful domestic lobbies, electoral cycles, and political fundraising requirements (Preeg, 1999; Drury, 2000; Fisk, 2000; Fayazmanesh, 2003; Gordon, 2010). Sanctions can also be used to create rents for domestic businesses, particularly non-tradable sectors which lobby for protectionist measures (Bergeijk, 1995: 446; Kaempfner and Lowenberg, 1992; Helms, 1999: 4; Fayazmanesh, 2003; Pospieszna et al., 2020).

Elites can also use sanctions to manage domestic order. Although sanctions are normally seen as a policy chosen by unitary state actors, in reality they can express efforts to resolve internal divisions within a state apparatus, e.g. to balance between those favouring diplomacy or war (Gordon, 2010). More broadly, elites can use sanctions to mobilise societal support for their wider political and ideological agendas. A policy aimed, for example, at containing revolutionary regimes like Cuba is "rarely just a foreign policy (...) it is also directed inwards, a nationalist identification of certain programmes of domestic political change with a foreign threat" (Rosenberg, 1994: 35). Particularly in the US, sanctions help maintain a crusading spirit against "evil" regimes, sustaining an environment favourable to the projection of power abroad (Christensen, 1996; Drolet, 2007).

Where any of these dynamics are present, it is insufficient to assess the success of sanctions solely by measuring the degree of target compliance. If sanctions are being used to appease domestic constituencies, we should pay attention to indicators of political support emanating from the imposition of sanctions, like opinion poll data. If they are being used to generate rents, the economic payoffs to domestic business must be calculated and their degree of satisfaction ascertained by observing their lobbying behaviour. If sanctions are being used to manage political order, we again need to use interpretive methods from political sociology and related disciplines to assess whether their purposes were achieved. None of these enterprises are easy, but without them 
any assessment of sanctions success is incomplete. These questions also open up space for more critical scholarship exploring the role sanctions play in state-society dynamics in powerful sender states.

\section{System-related goals}

System-related goals are arguably central to the use of sanctions yet are least well understood. Sanctions are deeply implicated in the establishment and maintenance of international norms and the policing of "deviance" by major powers as they seek to project their ideologies beyond their borders. From this perspective, sanctions constitute a form of global governance, an attempt to influence events in the absence of formal authority.

Sanctions are a means through which international society is produced and maintained. "International society" is understood here as "a grouping established by the coercion of some states by others and (...) maintained, with a variety of ideological and military mechanisms, by the more powerful members" (Halliday, 1994: 102). Sanctions are one mechanism used to sustain these arrangements. They help to manage regional balances-of-power (Barber, 1979; Lake, 1994; Fayazmanesh, 2003; Taylor, 2010). They are frequently used to contain challengers pursuing different ideological, political, social and economic projects to the hegemonic power; to prevent their systems being seen as desirable or imitable elsewhere; and to restrict their resources and thus their capacity for subversion elsewhere (Baldwin, 1985; Mercille and Jones, 2009).

Sanctions are frequently used to establish and enforce norms favoured by powerful states. They are routinely legitimised by reference to the need to defend international norms, which are typically presented as being in the general interest, rather than expressing the particular interests of senders (Doxey, 1980: 9 and 127). As well as enforcing existing norms, sanctions can also redefine them. Washington used sanctions on Iran to broaden the non-proliferation norm (Mallard, 2019). Sanctions also establish norms by delineating that which is abnormal; by creating and fixing categories like "backlash", "rogue" or "outlaw states", which are invariably non-Western, in opposition to "law-abiding" and "peaceful" states (Lake, 1994). Sanctions against Iraq, for instance, were valued by US Secretary of State James Baker as an opportunity to set "standards for civilized behaviour" and to "solidify the ground rule of the new [world] order" (cited in Tang, 2005: 61). Despite the fact that sanctions sometimes violate international law (Gordon, 2010; Hurd, 2005: 511), they position sender states as law-givers and enforcers. As Derrida (2003: 105) 
highlights, "the dominant power is the one that manages to impose and, thus, to legitimate, indeed to legalize... on a national or world stage, the terminology and thus the interpretation that best suits it in a given situation". From this perspective, sanctions can be seen as an ideological-coercive mechanism used to set new normative, legal and political standards that advance the agenda of dominant powers (Jones, 2015; Wilson and Yao, 2018). Sanctions with extraterritorial reach seek to extend de facto legal sovereignty over territories, actors and issues within the sovereign domain of other governments (Shambaugh, 1999; Bergeijk, 1995: 446-447).

Sanctions maintain hegemonic orders by creating norms, projecting power, and co-opting others into one's agenda. By "punishing" violators (Nossal, 1989), they signal to others that norm-violation is costly (Doxey, 2000: 213). Their use maintains the reputation

Sanctions can be seen as an ideologicalcoercive mechanism used to set new normative, legal and political standards that advance the agenda of dominant powers. and credibility of threats of punishment. And, if threats suffice - as much sanctions research suggests (Dashti Gibson et al., 1997; McGillivray and Smith, 2006; Letzkian and Souva, 2007) - then coercive power does not necessarily have to be deployed against potential offenders, confirming the hegemony attained by senders.

Crucially, sanctions are not merely used against senders' declared enemies. They are also employed to police alliance systems and to co-opt other states into dominant powers' agendas. Indeed, financial sanctions emerged historically from the tradition of punishing defectors from alliance systems (Kirshner, 1997: 37). Soviet sanctions against Yugoslavia were largely about maintaining the unity of the Warsaw Pact (Barber, 1979: 371). US sanctions against European firms in the 1980s were partly aimed at dissuading European states from continuing détente and instead to co-opt them into confrontating the Soviet Union (Shambaugh, 1999). As US Congressman Lee Hamilton put it, the ultimate goal of the 1996 Iran-Libya Sanctions Act was not to punish foreign firms, but "to persuade other governments to adopt measures that squeeze the economies and Iran and Libya" (quoted in Shambaugh, 1999: 185). Dollar hegemony gives US governments unparalleled power in this respect (Farrell and Newman, 2019). As former British Ambassador Nigel Gould-Davies (2020: 23) notes, it enables the US "not only to isolate a target from the global financial system but to enforce the compliance of other states through the threat of secondary sanctions on them". Sanctions can also help lay the ground for further measures, includ- 
ing military action, allowing coalitions to consolidate while creating the impression that peaceful means of conflict resolution have been exhausted (Barber, 1979: 372; Gordon, 2010: 6).

In turn, third countries may impose sanctions not out of a desire for compliance from their formal targets, but actually to appease others or align with allies (Hellquist, 2016). Russia and China imposed some embargoes on Iran and North Korea largely to create "bargaining chips" in their relations with the US (Taylor, 2010). Similarly, members of the European Community imposed sanctions on Argentina during the Falklands War not principally to coerce Buenos Aires but rather to align themselves with Britain (Doxey, 2000: 218). Likewise, Britain imposed sanctions on Rhodesia not because it expected to compel a system transition to majority rule but rather to satisfy outraged African opinion and forestall possible Soviet involvement.

As with sender-related goals, system-related goals can rarely be confirmed in a positivist fashion. They must instead be deduced from senders' foreign policies, their relations with other states, and how sanctions are implicated in the (re)production of world order. The measurement of success here is even more difficult. The extent to which a single sanctions regime contributes to the maintenance of a particular norm, for example, is virtually impossible to verify. We can only make counterfactual judgements about success here, by asking what might happen in the absence of sanctions regimes. We might also consider the reactions of third states and enquire to what extent sanctions influenced decision-makers: were they co-opted into a new policy or deterred from adopting one by sanctions? Again, such investigation involves exhaustive historical case studies and necessarily relies on interpretation.

\section{Multiple and interrelated goals}

For any one sanctions regime, policymakers may entertain many goals at once. For instance, an advocate of US sanctions against Cuba lists five goals: halting US policy drift; isolating the Castro regime; preparing the US state apparatus for a post-Castro transition; blocking foreign investment in Cuba; and promoting international property rights protection (Fisk, 2000). Inflicting costs on a state can be a goal in its own right and/ or a means of enforcing norms and deterring others. This would combine a target- with a system-related goal. Likewise, the sender-related goal of preparing a population for war is linked to a variety of system-maintenance goals. Evaluating success requires the achievement of each goal to be measured separately. 
Furthermore, a sense of how multiple goals interrelate and evolve over time may be vital to understanding the longevity of sanctions and their likelihood of success. Despite the official emphasis on compliance, it is often understood on both sides of a sanctions dispute that the real objectives may differ. As noted by Kim Elliott, "policymakers' true goals may be hidden behind the public rhetoric" (2010: 86). Cold War sanctions against Cuba may well have been more about American prestige and the containment of socialism than about ousting Fidel Castro (Baldwin, 1985: 108). This carries serious implications for compliance. If the target leadership believes that sanctions are being used to pander to domestic audiences, it is unlikely to be persuaded that compliance with the official goals will bring them any relief. It is more likely to believe that sanctions will persist until their unofficial goals are met, or that the formal goals will evolve until the underlying motives are satisfied. Targeted leaderships often express concerns along these lines, claiming that sanctions are about containment, motivated by the desire to halt the target country's progress (Kluge, 2019), or arguing that if they complied with senders' demands, the goalposts would only shift (Aljazeera, 2006).

\section{Conclusions}

Although the complexity, multiplicity and interrelatedness of policymakers' goals was identified in the first phase of research on international economic sanctions, these insights were subsequently ignored and sorely need refreshing. Nowadays, even when scholars do identify multiple goals, most still tend to measure success solely in terms of target's compliance with official, target-related goals (e.g. Preeg, 1999). Yet, not only is there little agreement on how to properly measure even this narrow conception of success, a fixation on target-related goals has impeded full understanding of the place sanctions have in the (re)production of domestic order in target and sender states and global order more broadly. The existing sanctions literature on sanctions success, though vast, is fundamentally flawed. More research is needed to develop a better understanding of the multiplicity of motives behind sanctions, and on how to measure success for each goal.

Broadening our understanding of goals should be accompanied by greater critical scrutiny. Consciously or otherwise, many scholars often see their role as defending sanctions and counselling policymakers on their use. Consequently, the risk of broadening the criteria for success is that it might become 
another way to defend sanctions from criticism that they inflict suffering on targets without eliciting compliance, by pointing to other goals being met. This is a particular hazard where the mere act of imposing sanctions may confer success easily or even automatically, e.g. appeasing allies or signalling. This is all the more reason for a more critical approach to sanctions than that taken in mainstream literature. If we find that sanctions are successful in delivering sender-related goals, like rallying populations for war, and system-related goals, like corralling allies into ostracising "rogue" states, but unsuccessful in delivering target-related goals, we should not uncritically celebrate "partial" success. Such a finding would imply that individual states are being singled out to enable great powers' strategies of global governance (Gordon, 2010). This ought to be cause for concern and normative debate, not optimism or celebration.

\section{Bibliographical references}

Aljazeera. "Removing Saddam strengthened Iran" (5 September 2006) (online) [Accessed 21/04/2020] https://www.aljazeera.com/archi ve/2006/09/200849131514551633.html

Baldwin, David. Economic Statecraft. Princeton: Princeton University Press, 1985.

Baldwin, David. "The Sanctions Debate and the Logic of Choice". International Security, vol. 24, issue 3 (2000), pp. 80-107.

Baldwin, David; Pape, Robert. "Evaluating Economic Sanctions". International Security, vol. 23, issue (1998), pp. 189-98.

Barber, James. "Economic Sanctions as a Policy Instrument". International Affairs, vol. 55, issue 3 (1979), pp. 367-84.

Bergeijk, Peter van. "The Impact of Economic Sanctions in the 1990s". World Economy, vol. 18, issue 3 (1995), pp. 443-55.

Biersteker, Thomas; Eckert, Sue; Tourinho, Marcos. (eds.) Targeted Sanctions: The Effectiveness of UN Action. Cambridge: Cambridge University Press, 2016.

Blanchard, Jean-Marc; Ripsman, Norrin. "Asking the Right Question: When do Economic Sanctions Work Best?”, Security Studies, vol. 9, issue 1 (1999), pp. 219-53.

Blanchard, Jean-Marc; Ripsman, Norrin. "A Political Theory of Economic Statecraft". Foreign Policy Analysis, vol. 4, issue 4 (2008), pp. 371-398.

Borzyskowski, Inken v.; Portela, Clara. "Sanctions Cooperation and Regional 
Organisations”. In Aris, Stephen; Snetkov, Aglaya; Wenger, Andreas (eds.) Inter-organisational Relations in International Security: Cooperation and Competition. Abingdon: Routledge, 2018, pp. 240-261.

Brooks, Risa. "Sanctions and Regime Type: What Works and When?". Security Studies, vol. 11, issue 4 (2002), pp. 1-50.

Brzoska, Michael. "Research on the Effectiveness of International Sanctions". In: Hegemann, Hendrik; Heller, Regina; Kahl, Martin (eds.) Studying "Effectiveness" in International Relations. Opladen: Budrich, 2013, pp. 143-60.

Chesterman, Simon; Pouligny, Beatrice. "Are Sanctions Meant to Work? The Politics of Creating and Implementing Sanctions through the United Nations". Global Governance, vol. 9, issue 4 (2003), pp. 503-18.

Christensen, Thomas J. Useful Adversaries: Grand Strategy, Domestic Mobilization, and Sino-American Conflict, 1947-1958. Princeton: Princeton University Press, 1996.

Cortright, David; George Lopez. The Sanctions Decade: Assessing UN Strategies in the 1990s. Boulder: Lynne Rienner, 2000.

Crawford, Neta; Klotz, Audrey (eds.) How Sanctions Work: Lessons from South Africa. New York: St. Martin's, 1999.

Dashti-Gibson, Jaleh; Davis, Patricia; Radcliff, Benjamin. "On the Determinants of the Success of Economic Sanctions: An Empirical Analysis". American Journal of Political Science, vol. 41, issue 2 (1997), pp. 606-18.

Derrida, Jacques. "Autoimmunity: Real and Symbolic Suicides - A Dialogue with Jacques Derrida". In: Borradori, Giovanna (ed.) Philosophy in a Time of Terror: Dialogues with Jürgen Habermas and Jacques Derrida. Chicago: University of Chicago Press, 2003, pp. 85-136.

Doxey, Margaret. Economic Sanctions and International Enforcement, 2nd ed. London: Macmillan, 1980.

Doxey, Margaret. "Sanctions through the Looking Glass: The Spectrum of Goals and Achievements". International Journal, vol. 55, issue 2 (2000), pp. 207-223.

Doxey, Margaret. "Reflections on the Sanctions Decade and Beyond". International Journal, vol. 64, issue 2 (2009), pp. 539-549.

Drezner, Daniel W. The Sanctions Paradox: Economic Statecraft and International Relations. New York: Cambridge University Press, 1999.

Drolet, Jean-Francois. "The Visible Hand of Neo-Conservative Capitalism". Millennium, vol. 35, issue 2 (2007), pp. 245-278.

Drury, Cooper. "Revisiting Economic Sanctions Reconsidered". Journal of Peace Research, vol. 35, issue 4 (1998), pp. 497-509.

Drury, Cooper. "How and Whom the US President Sanctions: A Time-Series Cross-Section Analysis of US Sanction Decisions and Characteristics". In: 
Chan, Stephen; Drury, Cooper (eds.) Sanctions as Economic Statecraft: Theory and Practice. London: Macmillan, 2000, pp. 17-36.

Drury, Cooper. "Sanctions as Coercive Diplomacy: The U.S. President's Decision to Initiate Economic Sanctions". Political Research Quarterly, vol. 54, issue 3 (2001), pp. 485-508.

Elliott, Kimberly A. "Factors Affecting the Success of Sanctions". In: Cortright, David; Lopez, George (eds.) Economic Sanctions. Panacea or Peacebuilding in a Post-Cold War World? Boulder: Westview Press, 1995, pp. 5159.

Elliott, Kimberly A. "The Sanctions Glass: Half Full or Completely Empty?”, International Security, vol. 23, issue 1 (1998), pp. 50-65.

Elliott, Kimberly A. "Assessing UN Sanctions After the Cold War", International Journal, vol. 65, issue 1 (2010), pp. 86-97.

Elliott, Kimberly A. and Uimonen, Peter. "The Effectiveness of Economic Sanctions with Application to the Case of Iraq". Japan and the World Economy, vol. 5, issue 4 (1993), pp. 403-409.

Escribà-Folch, Abel. "Authoritarian Responses to Foreign Pressure: Spending, Repression, and Sanctions". Comparative Political Studies, vol. 45, issue 6 (2012), pp. 683-713.

Farrell, Henry; Newman, Abraham. "Weaponized Interdependence: How Global Economic Networks Shape State Coercion". International Security, vol. 44, issue 1 (2019), pp. 42-79.

Fayazmanesh, Sasan. "The Politics of the US Economic Sanctions against Iran”. Review of Radical Political Economics, vol. 35, issue 3 (2003), pp. 221-240.

Fisk, Daniel W. "Economic Sanctions: The Cuba Embargo Revisited". In: Chan, Stephen; Drury, Cooper (eds.) Sanctions as Economic Statecraft: Theory and Practice. London: Macmillan, 2000, pp. 65-85.

Galtung, Johann. "On the Effects of International Economic Sanctions, with Examples from the Case of Rhodesia", World Politics, vol. 19, issue 3 (1967), pp. 378-416.

Giumelli, Francesco. "The Purposes of Sanctions". In: Biersteker, Thomas; Eckert, Sue; Tourinho, Marcos. (eds.) Targeted Sanctions. The Effectiveness of UN Action. Cambridge: Cambridge University Press, 2016, pp. 38-59.

Gordon, Joy. Invisible War: The United States and the Iraq Sanctions. Cambridge, MA: Harvard University Press, 2010.

Gould-Davies, Nigel. "Russia, the West and Sanctions". Survival, vol. 62, issue 1 (2020), pp. 7-28.

Haas, Richard N. "Sanctioning Madness". Foreign Affairs, vol. 76, issue 6 (1997), pp. 74-85. 
Halliday, Fred. Rethinking International Relations. London: Macmillan, 1994. Hellquist, Elin. "Either With us or Against us? Third-Country Alignment with EU Sanctions against Russia/Ukraine". Cambridge Review of International Affairs, vol. 29, issue 3 (2016), pp. 997-1.021.

Helms, Jesse. "What Sanctions Epidemic? US Business' Curious Crusade". Foreign Affairs, vol. 78, issue 1 (1999), pp. 2-8.

Hoffmann, Fredrik. "The Functions of Economic Sanctions: A Comparative Analysis", Journal of Peace Research vol. 4, issue 2 (1967), pp. 140-159

Hufbauer, Gary C.; Jeffrey Schott; Elliott, Kimberly. Economic Sanctions Reconsidered: History and Current Policy, 1st ed. Washington, DC: Petersen Institute for International Economics, 1985.

Hurd, Ian. "The Strategic Use of Liberal Internationalism: Libya and the UN Sanctions, 1992-2003”, International Organization, vol. 59, issue 2 (2005), pp. 495-526.

Jones, Catherine. "Sanctions as Tools to Signal, Constrain, and Coerce". Asia Policy, vol. 13, issue 3 (2018), pp. 20-27.

Jones, Lee. Societies under Siege: Exploring How International Economic Sanctions (Do Not) Work. Oxford: Oxford University Press, 2015.

Kaempfner, William; Lowenberg, Anton. International Economic Sanctions: A Public Choice Approach. Oxford: Westview Press, 1992.

Kirshner, Jonathan. "The Microfoundations of Economic Sanctions". Security Studies, vol. 6, issue 3 (1997), pp. 32-64.

Kirshner, Jonathan. "Economic Sanctions: The State of the Art". Security Studies, vol. 11, issue 4 (2002), pp. 160-79.

Kluge, Janis. "Taking Stock of US Sanctions on Russia”. Philadelphia: Foreign Policy Research Institute (14 January 2019) (online) [Accessed 24/04/2020] https://www.fpri.org/article/2019/01/taking-stock-of-u-s-sanctions-onrussia/

Lake, Anthony. "Confronting Backlash States", Foreign Affairs vol. 73, issue 2 (1994), pp. 45-55.

Lektzian, David; Souva, Mark. "An Institutional Theory of Sanctions Onset and Success". Journal of Conflict Resolution, vol. 51, issue 6 (2007), pp. 848-871.

Lindsay, James M. "Trade Sanctions as Policy Instruments: A Re-examination”. International Studies Quarterly, vol. 30, issue 2 (1986), pp. 153-173.

Lopez, George; Cortright, David. "Containing Iraq: Sanctions Worked”. Foreign Affairs, vol. 83, issue 4 (2004), pp. 90-103.

Mack, Andrew; Kahn, Asif. "The Efficacy of UN Sanctions". Security Dialogue, vol. 31, issue 3 (2000), pp. 279-292.

Mallard, Gregoire. "Governing Proliferation Finance: Multilateralism, Trans- 
governmentalism, and Hegemony in the Case of Sanctions against Iran”. In: Brousseau, Eric; Glachant, Jean-Michel; Sgard, Jerome (eds.) The Oxford Handbook of Institutions of International Economic Governance and Market Regulation, Oxford: Oxford University Press, 2019, pp. 1-21.

McGillivray, Fiona; Smith, Alistair. "Credibility in Compliance and Punishment: Leader Specific Punishments and Credibility”. Journal of Politics, vol. 68, issue 2 (May 2006), pp. 248-258.

Mercille, Julien; Jones, Alun. "Practicing Radical Geopolitics: Logics of Power and the Iranian Nuclear 'Crisis'". Annals of the Association of American Geographers, vol. 99, issue 5 (2009), pp. 856-862.

Miller, Nicholas L. "The Secret Success of Non-Proliferation Sanctions". International Organization, vol. 68, issue 4 (2014), pp. 913-944.

Nooruddin, Irfan. "Modelling Selection Bias in Studies of Sanctions Efficacy". International Interactions, vol. 28, issue 1 (2002), pp. 59-75.

Nossal, Kim. "International Sanctions as International Punishment". International Organization, vol. 43, issue 2 (1989), pp. 301-322.

Thinan, Myo Nyun. "Feeling Good or Doing Good: Inefficacy of the US Unilateral Sanctions against the Military Government of Burma/Myanmar". Washington University Global Studies Law Review vol. 7, issue 3 (2008), pp. 455-518.

Pape, Robert. "Why Economic Sanctions do not Work". International Security, vol. 22, issue 2 (1997), pp. 90-136.

Pape, Robert. "Why Economic Sanctions Still do not Work". International Security, vol. 23, issue 1 (1998), pp. 66-77.

Peksen, Dursun. "When Do Imposed Economic Sanctions Work? A Critical Review of the Sanctions Effectiveness Literature". Defence and Peace Economics, vol 30, issue 6. (2019), pp. 634-647.

Portela, Clara. European Union Sanctions and Foreign Policy. London: Routledge, 2010.

Pospieszna, Paulina; Skrzypczy ska, Joanna; St pie, Beata. "Hitting Two Birds with One Stone: How Russian Countersanctions Intertwined Political and Economic Goals". Political Science \& Politics, vol. 53, issue 2 (2020), pp. 243-247.

Preeg, Ernest H. Feeling Good or Doing Good with Sanctions: Unilateral Economic Sanctions and the U.S. National Interest. Washington, DC: CSIS Press, 1999.

Rosenberg, Justin. The Empire of Civil Society: A Critique of the Realist Theory of International Relations. London: Verso, 1994.

Rowe, David M. Manipulating the Market: Understanding Economic Sanctions, Institutional Change, and the Political Unity of White Rhodesia. Ann Arbor: University of Michigan Press, 2001. 
Shambaugh, George. States, Firms, and Power: Successful Sanctions in United States Foreign Policy. Albany: State University of New York Press, 1999. Tang, Shiping. "Reputation, Cult of Reputation, and International Conflict". Security Studies, vol. 14, issue 1 (2005), pp. 34-62.

Taylor, Brendan. Sanctions as Grand Strategy. London: IISS, 2010.

Tsebelis, George. "Are Sanctions Effective? A Game Theoretical Analysis". Journal of Conflict Resolution, vol. 34, issue 1 (1990), pp. 3-28.

US Government. "Burmese Freedom and Democracy Act of 2003". Congress. gov, Public Law 108-161, (28 July 2003) (online) https://www.congress. gov/108/plaws/publ61/PLAW-108publ61.pdf

Wilson, Peter; Yao, Joanne. "International Sanctions as a Primary Institution of International Society". In: Brems Knudsen, Tonny; Navari, Cornelia (eds.) International Organization in the Anarchical Society. Cham: Palgrave Macmillan, 2018, pp. 127-148. 